\title{
ДОКСА И СВАКОДНЕВНИ ЖИВОТ
}

Текст који следи је уређен транскрипт дискусије Пјера Бурдијеа и Терија Иглтона - вођене у оквиру серије „Приче о идејама/Идеје које причају“ (“Talking Ideas”) - у Институту савремених уметности (Institute of Contemporary Arts) у Лондону 15. маја 1991.

Тери Иглтон: Поздрав свима и добродошли. Пјер Бурдије и ја ћемо да расправљамо о неким темама које се појављују у нашим новим књигама - пре свега у његовој: Језик и симболичка моћ, али и у мојој студији: Идеологијаㄹ. Након тога ћемо да вас замолимо за коментаре и да одговарамо на ваша питања.

Хтео бих да ти пожелим добродошлицу, Пјер, приликом једне од твојих превише ретких посета овој земљи. Изузетно нам је драго што те видимо и што имамо превод твојих огледа у овој књизи. Једна од тема којом се бавиш у свом раду тиче се језика који је, колико средство комуникације, толико - ако не и

\footnotetext{
${ }^{1}$ In Conversation, Pierre Bourdieu and Terry Eagleton "Doxa and Common Life", New Left Review, I/191 (Jan/Feb 1992): 111-121. (www.newleftreview.org; https://newleftreview.org/issues/I191/ articles/terry-eagleton-pierre-bourdieu-doxa-and-common-life)

Синтагма “common life” је овде преведена као „свакодневни живот“. Она је у оригиналном наслову намерно употребљена да би „покрила“ вишезначност речи “common”: „обичан“, „заједнички“, „свакодневни“, али и „прост“ (у смислу „не-аристократски“ или „не-елитни“). Рејмонд Вилијамс, кога Иглтон у овом разговору помиње и од кога „преузима“ овај израз, често употребљава "common life” у веома утицајној књизи Култура и друштво (Raymond Williams Culture and Society 1780-1950, London: Chatto \& Windus, 1958).

За етимологију и контексте употребе видети одредницу "Common" y: Raymond Williams Keywords: a vocabulary of culture and society (revised edition), New York: Oxford University Press, 1983: 70-72, затим одредницу “Common culture“ у: Chris Barker - The SAGE Dictionary of Cultural Studies, London: SAGE, 2004: 29-30, а нарочито текст Стјуарта Хола из 1993. године: Stuart Hall "Culture, community, nation", Cultural Studies 7(3): 349-363, посебно стр. 351 где он пише о Вилијамсовом прелазу са „апстрактне“ дефиниције културе као „стања или процеса људске перфекције“, на одређење културе као „описа посебног начина живота који изражава одређена значења и вредности, не само у уметности и образовању, већ и у институцијама и уобичајеном/ свакодневном понашању“" (прим. прев.)

${ }^{2}$ Pierre Bourdieu, Language and Symbolic Power, Cambridge: Polity Press, 1991 (Što znači govoriti: ekonomija jezičnih razmjena, Zagreb: Naprijed, 1992; оригинално издање: Ce que parler veut dire: l'économie des échanges linguistiques, Paris: Fayard, 1982; у енглеском издању има додатног материјала, али су нека од поглавља из француског изостављена; интегрална верзија је објављена 2001. као: Language et pouvoir symbolique, Paris: Éditions du Seuil - прим. прев.); Terry Eagleton, Ideology, London: Verso, 1991.
} 
више - инструмент моћи и делања (action). Ово је тема која прожима све о чему пишеш у овој књизи и то те наводи да заузмеш један прилично непријатељски став, како ја то видим, према било каквој чистој семиотици. Уместо семиотичким разматрањима, ти посвећујеш пажњу ономе што на једном месту називаш „друштвеним условима производње исказа“" и такође, претпостављам, условима рецепције исказа. Другим речима, ти заступаш тезу да оно што је битно у (раз)говору, у дискурсу, није нека моћ инхерентна самом језику, већ врста ауторитета или легитимитета којом је он подржан. То те онда наводи да мобилишеш концепте - са којима је, верујем, већина нас упозната из твојих других дела - као што су „симболичка моћ“, „симболичко насиље“, „лингвистички капитал“ и други. Хтео бих да те питам да ли сам ово исправно разумео и да те замолим да објасниш како ови процеси могу да се доведу у везу са појмом идеологије - да ли су они синонимни или је идеологија за тебе нешто сасвим друго? Концепт идеологије понекад искрсне у твом раду ${ }^{3}$, али није централни проблем ове посебне књиге.

Пјер Бурдије: Хвала ти за ово што кажеш о мојој књизи; у само неколико реченица сажео си њену главну намеру, тако да је мени сада лакше да одговорим на питање. Ја се, заправо, трудим да избегнем реч „идеологија“ због тога што је, како твоја књига и показује, често била злоупотребљавана или употребљавана врло нејасно. Чини се да она носи једну врсту дискредитације. Описати изјаву као идеолошку је врло често увреда, тако да ово приписивање са̂мо постаје средство симболичке доминације. Покушао сам да појмовима као што су „симболичка доминација“ или „симболичка моћ“ заменим појам идеологије у циљу покушаја контроле неких од начина употребе, или злоупотребе, којима је подложан. Појмом симболичког насиља покушавам да учиним видљивим један неопажен облик свакодневног насиља. На пример, овде, у овој дворани сада, ја се осећам врло стидљиво; ја сам узнемирен и имам потешкоћа при формулисању својих мисли. Трпим јак облик симболичког насиља који је повезан са чињеницом да језик (којим говоримо) није мој и да се не осећам опуштено пред овом публиком. Ја мислим да концепт идеологије не би могао да пренесе то, или би то учинио на један општији начин. Понекад морамо да „реновирамо“ појмове - прво, да би били прецизнији, и друго, да бисмо их учинили животнијим. Сигуран сам да се слажеш да је појам идеологије био толико употребљаван и злоупотребљаван да више не ради. Изгубили смо веру у њега; а важно је, на пример у политичком контексту, поседовати појмове који

\footnotetext{
${ }^{3}$ Видети: Pierre Bourdieu \& Luc Boltanski « La production de l'idéologie dominante », Actes de la recherche en sciences sociales 2/3 (1976): 4-73. Редигована верзија овог текста је објављена као књига 2008. године, уз детаљне коментаре Лика Болтанског које је насловио: Rendre la réalité inacceptable. À propos de "La production de l'idéologie dominante » (Чињење стварности неприхватљивом. Коментари на „Производну доминантне идеологије “). Такође видети: Simon Susen "Reflections on Ideology: Lessons from Pierre Bourdieu and Luc Boltanski", Thesis Eleven 124(1) (2014): 90-113. и Simon Susen "Towards a Critical Sociology of Dominant Ideologies: An Unexpected Reunion between Pierre Bourdieu and Luc Boltanski”, Cultural Sociology 10(2) (2015): 195-246 (прим. прев.).
} 
су ефикасни и делотворни.

Т. И. Ово ме подстиче да објасним зашто ја и даље пишем о идеологији, иако се слажем са овим што кажеш - да је овај појам често нејасан, као и са тим да је у оптицају много различитих схватања идеологије. Моја књига је делом била покушај да се тај појам разјасни. И ја мислим да сада постоје разлози због којих се појам идеологије чини сувишним или непотребним, те се бавим и њима у својој књизи. Један од тих разлога је схватање по коме изгледа да теорија идеологије зависи од схватања репрезентације/представљања, где су одређени модели представљања доведени у питање, а тиме такође, како неки мисле, и појам идеологије. Други разлог - можда мало занимљивији - је да се сада често осећа да морате да имате неку врсту приступа апсолутној истини да бисте одређени облик мишљења могли да идентификујете као идеолошки. Ако се идеја апсолутне истине доведе у питање онда изгледа да са њим пада и појам идеологије.

Постоје још два додатна разлога због којих се чини да идеологија више није концепт који је у моди. Један је оно што је названо „просвећена лажна свест“. Наиме, чини превише поједностављеном идеја да у постмодерној епохи деламо с лажном свешћу (о томе шта радимо). Људи су, заправо, много више цинично или лукаво свесни својих вредности него што би могло да се претпостави. Ово поново доводи појам идеологије у питање. Коначно, ту је и аргумент да је оно што одржава рад система у мањој мери реторика или дискурс, а више његова сопствена системска логика: идеја да развијени капитализам ради сам од себе, да му не треба да прође кроз свест да би био потврђен, да некако обезбеђује сопствену репродукцију. Ја, искрено, сумњам да је све ово довољно за одбацивање појма идеологије. Прихватам да ове различите примедбе имају одређену тежину, али претпостављам да је један разлог због кога желим да задржим концепт идеологије тај што мислим да постоји нешто што одговара појму лажне свести, и том погледу сам заинтересован за твој рад. Могу ли то овако да кажем: када користиш појмове као докса, спонтано веровање или мишљење, онда у извесном смислу они функционишу као појмови идеологије за тебе, с тим што би се докса чинила неупитном и природном. С друге стране, да ли ти то дозвољава да говориш о лажној свести у смислу лажних појмова или претпоставки које заправо (п)одржавају неправедне системе моћи? Да ли би желео да говориш о лажној свести само у смислу натурализације или универзализације, или би хтео да причаш у више епистемолошком смислу о односу лажних или истинитих идеја и друштвене стварности?

П. Б. Слажем се са првим делом твог расуђивања - са сумњама које си изнео о појму идеологије. Слажем се и могу даље да развијам твоје примедбе. Конкретно, мислим да је један од главних разлога употребе појма идеологије била потреба да се направи одлучно одвајање научника од других. На пример, Алтисер и они на које је утицао су врло симболички насилно користили овај концепт. Употребљавали су га као врсту религијске идеје уз помоћ које се 
поступно уздиже до истине, без сигурности да је достигнута истинска марксистичка теорија. Теоретичар је могао да каже: „Ви сте идеолог“. На пример, Алтисер је с омаловажавањем говорио о „такозваниим друштвеним наукама““ То је био манир којим се чинила видљивим врста раздвајања између истинског знања - које је у поседу науке - и лажне свести ${ }^{4}$. То је, по мом мишљењу, врло аристократски - и без сумње је Алтисеров аристократски начин мишљења један од разлога због којег не волим реч „идеологија“.

Да сада пређем на познатији терен: зашто мислим да је појам доксе кориснији? Многе ствари које се називају идеологијом у марксистичкој традицији, заправо функционишу на врло нејасан начин. На пример, могу да кажем да су сви академски системи, сви образовни системи, једна врста идеолошког механизма; они чине механизам који производи неједнаку расподелу личног капитала и они легитимишу ову производњу. Ти механизми су несвесни. Они су прихваћени и то је нешто веома моћно, што, по мом мишљењу, није схваћено у традиционалној дефиницији идеологије као репрезентације, као лажне свести. Мислим да марксизам, у ствари, остаје једна врста картезијанске филозофије, где имате свесног чиниоца који је учењак, учена особа, и друге који немају приступ свести. Превише смо причали о свести, превише разматрали проблем кроз категорију репрезентације. Друштвени свет не ради по принципу свести/ свесности; он ради кроз праксе, механизме и тако даље. Кад користимо доксу, прихватамо много ствари, а да то не знамо, и то се назива идеологијом ${ }^{5}$. Ја сматрам да морамо да радимо са филозофијом промене. Морамо да се одмакнемо од картезијанске филозофије марксистичке традиције према другачијој филозофији у којој чиниоци не теже свесно према стварима или су погрешно вођени лажним представама. Мислим да је све то погрешно и не желим да верујем у то.

Т. И. Ако сам те разумео, теорију доксе бисмо могли да назовемо много адекватнијом теоријом идеологије. Али, две ствари, које бих хтео да објасним, ме брину у вези са том реформулацијом. Једна је да концепт доксе наглашава

\footnotetext{
${ }^{4}$ Видети: Louis Althusser - Pour Marx, Paris: François Maspero, septembre 1965 (Луј Алтисер - $3 a$ Маркса, Београд: Нолит, 1971.); Louis Althusser, Étienne Balibar, Roger Establet, Pierre Macherey et Jacques Rancière - Lire le Capital, Paris: François Maspero, novembre 1965 (Louis Althusser i Etienne Balibar - Kako čitati Kapital, Zagreb: Centar za kulturnu djelatnost Saveza socijalističke omladine, 1975.); и поглавље: « Le discours d'importance : quelques réflexions sociologiques sur 'Quelques remarques critiques à propos de Lire le Capital' » из Бурдијеове књиге о економији језичких размена („„Важни’ дискурс, Неколико социолошких размишљања о 'Неколико критичких опаски у поводу књиге “Како читати Капитал”“, стр. 177-196. у преводу). Такође: William S. Lewis "Knowledge versus 'Knowledge': Louis Althusser on the Autonomy of Science and Philosophy from Ideology”, Rethinking Marxism 17(3)(2005): 455-470 (прим. прев.).

${ }^{5}$ Упоредити са Марксовом описним одређењем идеологије: „Sie wissen das nicht, aber sie tun es“ („Они то не знају али чине то“, Капитал I, Београд: Просвета, 1978: 76). Видети: Славој Жижек „Фетиш, идеологија и разлика“, Филозофска истраживања 16(6)(1988): 43-56; и: Slavoj Žižek - The Sublime Object of Ideology, London: Verso, 1989: 24-33 (Sublimni objekt ideologije, Zagreb: Arkzin, 2002) (прим. прев.).
} 
натурализацију идеја. Док ово дозвољава некоме да тражи несвесне механизме, није ли сувише једноставно тврдити да је целокупно симболичко насиље или идеологија у ствари натурализована? То јест, не могу ли људи некако да буду критичнији, чак сумњичавији, према тим вредностима и веровањима, а да им се ипак саображавају? Другим речима, зар мало не пренаглашаваш натурализујућу функцију идеологије или доксе? И друго, зар ниси у опасности да пребрзо прихватиш идеју да људи легитимишу преовлађујуће облике моћи? По свој прилици постоје различите врсте легитимације, све од апсолутне интернализације владајућих идеја до прагматичнијег или скептичког прихватања. Колико места твоја доктрина оставља тој врсти неслагања, критике и отпора?

П. Б. То је јако добро питање. Чак је и у традицији најнаглашенијег економизма коју знамо, наиме, марксизму, способност за отпор, као способност свести, прецењена. Бојим се да је оно што имам да кажем шокантно за самопоуздање интелектуалаца, посебно за либералније, левичарске интелектуалце. На мене гледају као на песимисту, као на оног који обесхрабрује људе и тако даље. Али ја мислим да је боље знати истину; и чињеница је да када видимо сопственим очима људе који живе у лошим условима - какви су постојали, када сам ја био млади научник, међу локалним пролетаријатом, радницима у фабрикама - јасно је да су они спремни да прихвате много више него што ми можемо да замислимо. То је за мене било веома упечатљиво искуство: они трпе много тога, и то подразумевам под доксом - да има пуно ствари које људи прихватају не знајући. Даћу вам пример узет из нашег друштва. Када једном узорку појединаца поставите питање који су главни чиниоци постигнућа у школи, што идете више ка доњем делу друштвене лествице више њих ће веровати у природне таленте или дарове - више ће веровати да су они који су успешни природно обдарени интелектуалним способностима ${ }^{6}$. И што више прихватају сопствено искључивање, више верују да су глупи, више њих ће рећи „Да, нисам био добар из енглеског, нисам био добар из француског, нисам био добар из математике“. То је чињеница - по мом мишљењу, то је ужасна чињеница - коју интелектуалци не воле да признају, али коју морају да признају. То не значи да доминирани појединци толеришу све; али они пристају на много више него што ми замишљамо и на много више него што мисле. То је страшан механизам, као империјални систем - чудесан инструмент идеологије, много већи и много моћнији него што је телевизија или пропаганда. Ово је главно искуство које желим да пренесем. Ово што кажеш за способност неслагања је веома важно; она заиста постоји, али не тамо где је тражимо - она узима други облик.

\footnotetext{
${ }^{6}$ Видети: Pierre Bourdieu et Jean-Claude Passeron - Les héritiers: Les étudiants et la culture, Paris: Les Editions de Minuit, 1964, и: Pierre Bourdieu et Jean-Claude Passeron - La reproduction: Éléments d'une théorie du système d'enseignement, Paris: Les Éditions de Minuit, 1970 (П. Бурдије, П. и Ж. К. Пасерон - Репродукиија: Елементи за једну теорију образовног система, Београд: Фабрика књига, 2014) (прим. прев.).
} 
Т. И. Да, ти заиста говориш о ономе што зовеш „хетеродоксија“"7, што је опозициона врста језика. Оно шта марксисти зову песимизмом у твом раду, ти би сам видео, вероватно, као реализам. Неко би могао да се сложи са тим, али с друге стране знам да ти не желиш да звучиш превише као Мишел Фуко. Ти не желиш, тиме што наглашаваш тај материјални реализам, да кренеш ка теорији моћи коју си сам критиковао, сматрам сасвим оправдано, као превише апстрактну, превише метафизичку, превише свепрожимајућу; и желиш да оставиш места за неку врсту политичког отпора. Мој приговор идеји доксе односи се на то да ти кажеш да постоји интернализација владајућих и тлачитељских веровања, али постоји, у следећем кораку, и нешто што може да буде сломљено и тиме омогућено појављивање хетеродоксије. Али, није ли све то (представљено) превише хронолошки? Можда карикирам, али није ли докса ствар пуна противречности? То јест, могу ли људи да верују и не верују, или верују на различитим нивоима?

П. Б. Не. То је повезано са програмом филозофије човека коју имамо, филозофијом делања/чина и тако даље. Рекао бих да докле год мислите у категоријама свести, лажне свести, несвесног и тако даље, не можете да схватите главне идеолошке ефекте, који се највећи део времена преносе кроз тело. Главни механизам доминације функционише кроз несвесну манипулацију телом. На пример, управо сам написао рад о процесима мушке доминације у такозваном примитивном друштву ${ }^{8}$. Они су исти као и ови у нашем друштву, само много видљивији. У првом случају, доминиране особе, жене, подлежу доминацији кроз телесно образовање. Могао бих да идем у детаље - на пример, девојке уче да ходају на одређени начин, оне уче да померају своја стопала на посебан начин, оне уче да крију своје груди. Кад уче да говоре, оне не кажу ,jа знам“; оне кажу ,ја не знам“. На пример, ако питате жену за правац, она ће рећи ,jа не знам“. Ми имамо еквивалентан процес, али он функционише на много суптилнији начин - кроз језик, кроз тело, кроз ставове о стварима који су испод нивоа свесног. Али он није механицистички; не упућује нас на несвесно. Чим почнемо да мислимо у тим категоријама, постаје јасно да је рад на еманципацији јако тежак; то је питање менталне гимнастике колико и развијања свести. А као интелектуалци ми нисмо навикнути на то. Ја то зовем схоластичком предрасудом - склоношћу којој смо сви изложени: ми мислимо да проблеми могу да буду решени само кроз свест. И ту се ја разликујем од

\footnotetext{
${ }^{7}$ Видети: Pierre Bourdieu - Outline of a Theory of Practice, Cambridge: Cambridge University Press, 1977: 159-171. Бурдије је за енглеско издање проширио и допунио ову књигу, између осталог управо и одељком “Doxa, Orthodoxy, Heterodoxy". Српскохрватско издање: Наupm за једну теорију праксе, Београд: Завод за уџбенике, 1999, рађено је према француском изворнику: Esquisse d'une théorie de la pratique, précédé de trois études d'ethnologie kabyle (Genève, Suisse: Librairie Droz, 1972) (прим. прев.).

${ }^{8}$ Pierre Bourdieu « La domination masculine », Actes de la recherche en sciences sociales 4(84) (sep 1990): 2-31. Из овог текста је настала књига истог наслова објављена 1998. године (у издању Raisons d'agir/Editions du Seuil). Енглески и српскохрватски превод су објављени 2001: Pierre Bourdieu - Masculine Domination, Cambridge: Polity Press; Пјер Бурдје - Владавина мушкараиа, Подгорица: ЦИД. (прим. прев.).
} 
Фукоа, и ту бих нагласио разлику у односу на његов значајан концепт дисциплине 9 . Дисциплина, барем на француском, упућује на нешто спољашње. Дисциплина се намеће војном силом; морате да се покорите. У једном смислу, лако је побунити се против дисциплине пошто сте је свесни. У ствари, мислим да у ситуацији симболичке доминације отпор тежи, пошто је она нешто што упијате као ваздух, нешто чији притисак не осећате; она је свуда и нигде, и веома је тешко избећи је. Радници су под овом врстом невидљивог притиска и тако они постају много прилагођенији њиховој ситуацији него што ми мислимо. Ово је јако тешко променити, посебно данас. Кроз механизам симболичког насиља доминација тежи да узме облик делотворнијег, и у овом смислу бруталнијег, средства угњетавања. Узмите за пример савремена друштва у којима насиље постаје меко, невидљиво.

Т. И. Претпостављам да у свему овоме има неке ироније, јер с једне стране ти реагујеш против нечега што видиш као стављање превеликог нагласка на свест. Мислим да си ту у праву, али неки од аутора из марксистичке традиције су то такође приметили. У исто време док си ти развијао ову теорију, марксистичка традиција је са̂ма, кроз рад Алтисера, колики год били његови недостаци, покушавала да пребаци појам идеологије на много мање свесну и много више практичну, институционалну раван, што га у неку руку можда приближава твојој позицији.

Хтео бих да размотрим тезу о политичкој опозицији или песимизму из друге перспективе, која карактерише битну област твог тренутног рада. Ти говориш врло смело и, ја мислим, врло маштовито, о лингвистичким тржиштима и цени или вредности исказа - „формирање цене“ - и ти намерно преносиш (и примењујеш) цео марксистички економски језик у културну или симболичку сферу; и говориш о пољу сукоба у коме људи покушавају да нагомилају неку количину културног капитала, да ли у образовању или уметности или где год. Мислим да је то у великој мери просветљујуће, посебно то што наглашаваш да при посматрању феномена уметности, не можемо да идемо директно на цело друштвено поље, већ морамо најпре да прођемо кроз посебно уметничко културно поље. Мислим да је ово од огромне користи. Међутим, зар не би могло да се тврди да си дошао до идеје целине људских пракси, делања и језика као рата, у коме ће играчи покушати да повећају свој улог, да инвестирају ефикасније на штету других играча? То је истинит опис многих поља нашег искуства, али зар не постоје други облици дискурса, други облици делања, који не би могли да буду тако лако концептуализовани као борбени?

П. Б. Ти сам дајеш добар пример чињенице да такви облици постоје, кроз брижљиво бављење мојим идејама! У сваком случају, то је важно питање које

\footnotetext{
${ }_{9}^{9}$ Видети: Michel Foucault - Surveiller et punir: Naissance de la prison, Paris: Gallimard, 1975 (Мишел Фуко - Надзирати и кажњавати: настанак затвора, Сремски Карловци; Нови Сад : Издавачка књижарница Зорана Стојановића, 1997); такође и: John S. Ransom - Foucault's Discipline: The Politics of Subjectivity, Durham; London: Duke University Press, 1997 (прим. прев.)
} 
ја постављам самом себи; слажем се да постоји проблем. Не знам зашто сам склон да мислим на тај начин - осећам да ме на то обавезује стварност. Мој утисак је да је ова врста размене у којој сада учествујемо неуобичајена. Када се ово деси, то је изузетак заснован на ономе што је Аристотел звао $\varphi \imath \lambda i \alpha$ (,philia“) - или пријатељство, да употребим општији израз. Фı $\lambda i ́ \alpha$ je, према Аристотелу, економска размена или симболичка размена коју можете да имате у оквиру породице, међу родитељима или међу пријатељима. Склон сам да мислим да је структура највећег броја поља, највећег броја игара, таква да је такмичење - борба за доминацију - квазинеизбежно. То је очигледно у економском пољу; али наћи ћете опис одговарајућим чак и за религијско поље. У већини поља, можемо да посматрамо оно што карактеришемо као такмичење за акумулацију различитих облика капитала (религијски капитал, економски капитал, и тако даље), и пошто су ствари такве какве су, неискривљена комуникација о којој пише Хабермас ${ }^{10}$ је увек изузетак. Можемо да остваримо ову неизобличену комуникацију само уз посебан труд када се за то испуне изванредни услови.

Рекао бих још само пар речи о аналогији између лингвистичке размене и економске размене, коју си управо поменуо. Ова аналогија је, по мом мишљењу, веома плодоносна у разумевању многих појава које не могу да се третирају једноставно као комуникација, као језичка производња. Неки енглески филозофи, као Остин, то су истакли; они су видели присуство веома важних ствари у језику - попут давања наредби, на пример, или издавања саопштења - које се не саображавају комуникационом моделу. Многе ствари не могу да се разумеју као примери чисте комуникације, и тако кад предлажем економску аналогију, ја само покушавам да уопштим и да пружим увиду аналитичке филозофије социолошку заснованост која му недостаје. Не критикујем Остина; кажем да он не даје потпуно објашњење друштвених услова који омогућују процесе које описује. Дакле, иако изгледа да сам јако далеко од ове филозофије језика, ја сам јој заправо јако близу.

Т. И. Јасно је да мислиш колико социолошки, толико и семиолошки. Кроз цео твој рад провејава једна врста постојаног подтекста дубоке преокупације условима сопственог рада - или општије речено, тешкоћама социолошког дискурса који тражи, било које добре, потенцијално еманципаторске, разлоге за анализу свакодневног живота (common life). То јест, постоји врло моћна преданост у твом раду - не увек експлицитна, али присутна као једна врста сензибилитета - ономе што бисмо могли да неадекватно назовемо „свакодневни живот“ ( 'the common life'). То је један од многих начина на који је твој рад упоредив са радом Рејмонда Вилијамса у Енглеској. Наравно да је тешко за социолога који је обухваћен веома специјализованим дискурсом да узме за предмет анализе

10 Jürgen Habermas - Theorie des kommunikativen Handelns (Handelungsrationalität und gesellschaftliche Rationalisierung. Bd. 1; Zur Kritik der funktionalistischen Vernunft. Bd. 2), Frankfurt am Main: Suhrkamp, 1981. (Јирген Хабермас - Теорија комуникативног деловағьа [1. Рачионалност деловања и друштвено рационализовање; 2. Критика функционалистичког ума], Нови Сад: Академска књига, 2017) (прим. прев.) 
или да тек размишља о том свакодневном животу. Ти, као и ја, не долазиш из породице интелектуалаца; и ја бих рекао да је твој рад врло занимљив због тога што је обележен напетошћу између, неког осећаја заједничке вредности који нема никакве везе са интелектом, с једне стране, и друге димензије која се умногоме тиче анализирања академске институције - друштвеним условима који утичу на интелектуалце и пратећим импликацијама. Да ли мислиш да овај биографски стицај околности помаже у објашњењу твојих преокупација?

П. Б. Ово што кажеш је веома саосећајно и великодушно. Тачно си изнео моје лично осећање. Покушавам да уклопим два дела мог живота, као и многи други интелектуалци прве генерације. Неки за то користе другачија средства - на пример, нађу решење у политичком деловању, у некој врсти друштвене рационализације. Мој главни проблем је у покушају да разумем шта ми се десило. Моја путања може да се опише као чудесна, претпостављам - успон на место где не припадам. И да бих могао да живим у свету који није мој, морам да покушам да разумем обе ствари: шта значи имати академски ум - како се такав ствара - и, у исто време, шта је изгубљено у његовом стицању. Из тог разлога, чак и ако је моје дело - моје целокупно дело - једна врста аутобиографије, то је рад за људе који имају исту врсту путање и исту потребу да је разумеју.

Т. И. Остало нам је времена за питања и коментаре. Да ли би неко желео да каже још нешто о некој од тема које су се појавиле у дискусији?

Као аргумент против концепта идеологије је наведено да је марксизам придавао људима превелику способност да препознају истину и да је мање вероватно да ће они који су ниже на друштвеној лествици (моћи) да је препознају. Није ли пре случај да људи који су ниже на тој лествици немају економску моћ која би им омогућила да учествују у групама за дискусије и ослободе се (стега) уског круга њиховог приватног живота и препознају неке другачије могућности? Да ли мислите да је удео овога значајнији од интелектуалних способности - да људи имају могућност да препознају шире истине, али их юихове економске и породичне ситуачије спречавају у томе?

Т. И. У својој књизи тврдим да је цео посао интернализовања, легитимисања ауторитативне моћи сложена ствар која захтева способност, интелигенцију. Потребна је извесна доза креативности чак и код прихватања да је неко дефинисан на негативан начин, да је ниско на лествици или да је угњетаван. Притом је, ја бих рекао, парадоксално да легитимација доминантне моћи никада није само пасивно дешавање - ствар (простог) уношења у себе; дакле способности које помињете морају да постоје чак и да би људи прихватили доминантну моћ, да би себе дефинисали у односу на њу. Рекао бих да се добар део рада Пјера Бурдијеа тиче услова под којима људи могу или не могу да стекну капитал.

П. Б. Постоји нека de facto подела рада у друштвеној производњи на основу главних врста искуства. Врло често особе које су у позицији да говоре 
о друштвеном свету не знају ништа о друштвеном свету, а људи који знају о друштвеном свету нису у могућности да о њему говоре. Ако је мало истинитих ствари речено о друштвеном свету, разлог за то лежи у овој подели. На пример, докса претпоставља знање, практично знање. Радници знају пуно: више него било који интелектуалац, више него било који социолог. Али, у извесном смислу, они то не знају, недостаје им инструмент да то схвате, да говоре о томе. Па онда имамо ту митологију о интелектуалцу који је способан да преобликује његова доксичка искуства, његово овладавање друштвеним светом, у једно изричито и лепо изражено излагање. Ово је врло тежак проблем због друштвених разлога. На пример, ако интелектуалац покуша да репродукује искуство радника, као у Француској после 1968, он наилази на искуство радника коме недостају навике/диспозиције интелектуалца. Многе од ствари које га запрепашћују су, заправо, сасвим уобичајене. Он мора да буде у стању да у своју визију укључи опис радничког искуства - чињеницу да је то искуство из његове тачке гледишта. А то је веома тешко. Један од разлога због којег интелектуалци не обраћају пажњу је, по мом мишљењу, што они имају пуно интереса повезаних са културним капиталом. Даћу вам један пример: мене је увек шокирало оно што је Маркс говорио о Прудону; био је веома строг према њему. Маркс је рекао: „Он је глупи француски малограђанин“"11; да Прудон само пише естетику са позиције грчких естета; да је Прудон јако наиван. Маркс је, са своје стране, учио грчки; када је имао осамнаест већ је знао да пише на грчком. С висине је гледао на Прудона као на слабо образованог малограђанина, док је Маркс добио класично образовање које доликује сину високог функционера пруске монархије. Овакве дистинкције су јако важне. Када тражите нешто вредно презира у марксизму, то је ту. То долази из ароганције интелектуалца са културним капиталом. Деловање и многи сукоби левичарских партија су повезани са тим: интелектуалци мрзе и презиру раднике или им се превише диве - што је један облик презрења. Врло је важно знати све ове ствари; и из тог разлога је процес самокритике - који неко може да вежба проучавајући интелектуалца, академски ум - виталан процес - он је, такорећи, нужан лични услов за било коју врсту комуникације о идеологији.

Могу ли да за тренутак пребацим вашу пажну на уметност. Занима ме начин на који се идеологија симболичког капитала заснива на уметности и естетици, коју нападате у обе дистинкиије. На крају своје књиге тврдите да

\footnotetext{
${ }^{11}$ Нисмо успели да лоцирамо овај навод. Маркс о Прудоновој „малограђанској сентименталности“ и о Прудону као „од главе до пете малограђанском економисти и филозофу“ пише (на француском) у писму Аненкову од 28. децембра 1846 (Karl Marx i Friedrich Engels - Rani radovi, Zagreb: Naprijed, 1961: 405-417) и годину дана касније у Misère de la philosophie (Беда филозофије, Београд: Култура, 1946). Поново се бави Прудоном у писму Јохану Баптисту фон Швајцеру од 24. јануара 1865, које је објављено из три дела у листу Соиијалдемократ (Der Social-Demokrat), у бројевима 16, 17 и 18 од 1, 3 и 5. фебруара 1865 године (енглески превод је доступан на интернет адреси: https://www.marxists.org/archive/marx/works/1865/letters/65_01_24.htm). Видети и: Robert Hoffman "Marx and Proudhon: A Reappraisal of Their Relationship", The Historian 29(3)(May 1967): 409-430 (прим. прев.).
} 
људи са свих нивоа друштвене лествице користе универзални класификациони систем. И они са врха и они са дна друштва прихватају Кантову естетику. Шта се дешава са економијом симболичких добара када се узме у обзир, на пример, тврдња Фредерика Џејмсона ${ }^{12}$ о пролиферацији нових културних кодова? Ако је истина да постоји пролиферација нових кодова, у каквом је то односу са вашом анализом симболичке моћи?

П. Б. То је тешко питање. По мом мишљењу, постоји виша тржишта, места на којима доминантни код остаје апсолутно делотворан; а то су места где се играју главне игре - то јест, академски систем (у Француској је то систем Великих школа [Grandes Écoles], место одакле се регрутују руководиоци). Пошто сам се бавио питањима културе, позваћу се на њих у свом одговору. Поново се јавља стара идеја да је масовна култура, популарна култура и тако даље, у порасту; да људи то не виде, да су подсвесно привржени разликама у културама. Један је облик владајућег шика међу интелектуалцима да се каже: „Види ове карикатуре“, или неки други културни предмет, „не приказују ли велику културну креативност?“. Таква особа вам говори: „Ви то не видите, али ја видим, и ја сам први који то види“. Увид је можда исправан, али постоји пренаглашавање могућности ових нових ствари да промене структуру расподеле симболичког капитала. Преувеличавати обим промене је, у извесном смислу, облик популизма. Збуњујете људе када кажете: „Погледајте, реп је сјајан“. Питање је: да ли ова музика заиста мења структуру културе? Ја мислим да је у реду рећи да је реп сјајан, и у једном смислу је то боље него бити етноцентричан и сугерисати да таква музика нема вредности; али заправо је један начин бивања етноцентричним када заборавите шта остаје доминантна форма у главним друштвеним играма и да још увек не можете да остварите симболички профит од репа. Мислим да свакако морамо да обраћамо пажњу на ове ствари, али постоји политичка и научна опасност у прецењивању њиховог културног утицаја. У зависности од места са кога говорим, могу да будем на једној или на другој страни.

Кажете да симболичко насиље јесте насиье. Шта под тим подразумевате?

П. Б. Верујем да насиље узима софистицираније форме. Један пример чине испитивања јавног мњења - барем у Француској. (Речено ми је да је овде другачије, али у Француској су та анкетирања софистициранији облик [с]хватања мишљења од једноставног контакта политичара и њихове публике.) Испитивања јавног мњења су пример оне врсте манипулације о којој смо причали - нови облик симболичког насиља за који нико не сноси пуну одговорност. Тре-

\footnotetext{
${ }^{12}$ Видети чланак: Fredric Jameson "Postmodernism, or the Cultural Logic of Late Capitalism”, New Left Review I/146 (July/Aug 1984): 53-92 (Fredric Jameson „Postmodernizam ili kulturna logika kasnog kapitalizma“, u: Ivan Kuvačić, Gvozden Flego (ur.) Postmoderna: nova epoha ili zabluda?, Zagreb: Naprijed, 1988: 187-232); и књигу: Fredric Jameson - Postmodernism: or The cultural logic of late capitalism, Durham: Duke University Press, 1991 (Фредрик Џемсон - Постмодернизам: логика културе касног капитализма, Подгорица: ЦИД, 2016) (прим. прев.).
} 
бало би ми два сата да вам објасним како оно ради, пошто је манипулација тако сложена. Не верујем да више од десеторо људи разуме шта се догађа - чак ни људи који организују те анкете. На пример, политичари - они који су у влади - не знају како процес функционише и тако су они њиме управљани. То је сложена структура са мноштвом различитих посредника: новинара, креатора анкета, интелектуалаца који их коментаришу, телевизијских интелектуалаца (који су веома важни за политички ефекат), политичара и тако даље. Све ове особе су у мрежи међуповезаности и свако мистификује друге и мистификује себе мистификујући друге. Нико није свестан процеса који оперише тако да нико не може да каже да Француском једноставно владају испитивања јавног мњења. Да би се то разумело, потребни су вам инструменти који су много префињенији од метода који се традиционално користе. То говорим свим вођама синдиката. Кажем им: касните; три рата смо испред вас, закаснили сте три класна рата; ратујете средствима која одговарају класним борбама деветнаестог века, а суочени сте с облицима моћи који су врло софистицирани.

Било ми јако занимљиво да чујем помињање „интелектуалца прве генерације“" и путање такве особе. Из очевидних разлога то је и даље прилично ретка врста; али пошто је та врста сад и сама дошла у време да оставља потомство, ита је са децом тих људи? Да ли они постају интелектуалии друге генеращије? Да ли се без проблема укључују у средюу класу или обликују неку врсту поткултуре? Ово питам обојииу, делом потио ме моје сопствено искуство тера да очајавам над оним што изгледа да се дешава - изгледа да следећа генерација у исто време губи чврстину традиције радничке класе и некако никада у потпуности не усваја традицију средюе класе - те ме занимају коментари интелектуалацуа прве генерације, какви сте ви, о овоме.

Т. И. Па, моја деца не би ни штапом додирнула интелектуалца! Мислим да гледају на образовање као на буржоаску идеологију, што је за њих јако згодно! У праву сте. Има нечега у ономе што кажете о томе кад је човек нит' тамо, нит' овамо, али не видим зашто би то нужно требало да буде извор очајања. Мислим да би могло да буде занимљиво бити у тој позицији, зар не? Та генерација, наравно, више не припада радничкој класи - као што ни њихови родитељи више не припадају радничкој класи - али они су видели своје родитеље у акцији и гаје особену сумњичавост према интелектуалцима. Другим речима, они не мисле да је одговор у томе да се буде интелектуалац.

Хтела/-о бих да се надовежем на тезу коју је Пјер Бурдије изнео у вези са младим интелектуалиима који говоре о репу и померању фокуса на културу. Зар не мислите да својим појмом „хабитуса“ долазите у опасност да замаглите утицај основних економских детерминанти на могућности људи за еманципацију - тако што говорите о капиталу и култури и идеологији, док, напослетку, ако они немају могућности да оду и прочитају књигу онда они на тај начин не могу да се еманципују? Друга ствар коју бих хтео/-ла да доведем у питање је концепт доксе. Ако људи интернализују сопствену доминацију, на 
неки начин подсвесно, и ако су у тој ситуащији срећни, зар ви онда не долазите у невољу покушавајући да оправдате идеју еманципаичије?

П. Б. Да ли ми кажете да сумњате да имам неку врсту интелектуалне предрасуде и да постоји само један начин да се избегне (доминација)? Да ли је то ваш утисак?

Критикујете младог интелектуалиа због тога ито говори о репу као да је то средство еманципације; али у ваш појам „хабитуса“ ви укључујете културу као детерминанту, а може бити да усредсређивање на културу на тај начин помера нагласак са економских детерминанти које и даље обезбеђују приступ средствима за еманциипащију.

Т. И. Пробао бих да ово питање формулишем овако: твоје концентрисање на културу помера нагласак са економских детерминанти које спречавају људе да се еманципују. Реагујеш на економизам тако што подижеш економски имагинаријум у сферу културе, уместо да региструјеш тежину материјалног и економског унутар културе.

П. Б. Можда си у праву. Склон сам да превише савијам штап, као што је говорио Мао Цедунг, док покушавам да исправим претходна претеривања. Економизам представља опасност за владајућу критичку визију у овој области. Тежим да инсистирам на другим аспектима, али можда грешим. Иако у глави имам уравнотеженију слику, имам тенденцију да у излагању својих идеја инсистирам на мање вероватним, мање видљивим аспектима - тако да сте можда у праву.

Т. И. Друго питање је занимљиво - о томе да људи интернализују тлачење и услед тога се осећају срећни док су тлачени. Зар не би требало да се брани тврдња да они не могу да буду заиста срећни ако су угњетавани?

Али ако говорите о подсвесном - ако део вашег подсвесног хабитуса одређује какви сте - онда постаје врло тешко да се оно промени. У реду, не можете да припишете срећу, али онда не можете да припишете ни тугу; с друге стране марксизам и идеологија би да задрже идеју о актеру који се бори против нечега што се чини неправедним. Са доксом се то губи; не почињете да се питате ита је поента - нема нагона за еманципацијом.

П. Б. Мислим да је ово питање о срећи веома важно. Доксички став не значи срећу; он значи телесно потчињавање, несвесно потчињавање, које може да указује на много интернализоване напетости, на много телесне патње. Тренутно спроводим истраживање ${ }^{13}$ у коме интервјуишем особе неодређеног друштвеног статуса - оне који заузимају места која су под утицајем снажних противречности. Притом покушавам да будем више сократски настројен него

\footnotetext{
${ }^{13}$ Бурдије највероватније прича о истраживању чији су резултати објављени у књизи: Pierre Bourdieu et al. - La Misère du monde, Paris: Éditions du Seuil, 1993 (The Weight of the World: Social Suffering in Contemporary Society, Cambridge: Polity Press, 1999). (прим. прев.)
} 
што је то случај кад се врши позитивистичко анкетирање: покушавам да им помогнем да изразе оно што трпе. Открио сам много патње која је била сакривена овим несметаним радом хабитуса. Он помаже људима да се прилагоде, али изазива интернализоване противречности. Када се ово деси, неки би, на пример, могли да постану зависници. Покушавам да помогнем особи која пати да добије јасан увид у своју ситуацију кроз неку врсту социоанализе спроведене у пријатељској атмосфери пуној подршке. Често када то радим појединци искусе неку врсту интелектуалног задовољства; кажу „Да, разумем шта ми се дешава“. Али, у исто време, то је јако тужно. Недостаје ми позитивно самопоуздање које имају психоаналитичари; они очекују да свест буде прича туге и одговарају тугом кад индивидуа каже: „Види шта ми се десило. Зар то није грозно?“ Социјални рад је, до неке мере, такав: када га обављате, он вас кажњава. Ово је ситуација која се јавља веома често и она не противречи ономе што говорим о докси. Неко може да буде јако добро прилагођен овом стању ствари, а да бол настаје услед чињенице интернализовања тихе патње, која може да нађе телесни израз у форми мржње окренуте ка себи, у самокажњавању.

са енглеског језика превео: Милош Јовановић 